\title{
Psychological Determinants of Academic Achievement in Accounting: Evidence from Brazil
}

\author{
Samuel de Paiva Naves Mamede ${ }^{\dagger}$ \\ Federal University of Uberlândia - UFU \\ Alessandra Vieira Cunha Marques ${ }^{\Omega}$ \\ Federal University of Uberlândia - UFU \\ Pablo Rogers ${ }^{*}$ \\ Federal University of Uberlândia - UFU \\ Gilberto José Miranda ${ }^{ \pm}$ \\ Federal University of Uberlândia - UFU
}

\begin{abstract}
The proposal of this research was to investigate the association between psychological variables and academic performance of 494 students of accounting of a Brazilian public University. We seek, therefore, to highlight some psychological variables to understand the behavior of students of accounting courses. The instrument used for data collection was a questionnaire based on five psychological constructs: self-efficacy, self-esteem, optimism, locus of control and self-control. Regression analyses were used to identify the influence of the explanatory variables on the academic performance coefficient, with the main results showing that: (i) the variable smoking has a direct impact on the academic achievement of students; (ii) the academic performance of women is higher than that of men; (iii) students within the age range of 20 to 40 years have significantly lower performance than students of other age ranges, and (iv) the variable experience time in accounting is related with the students' performance.
\end{abstract}

Keywords: Student performance. Psychological scales. Locus of control.

Received in 28/08/2014; revised in 13/10/2014; accepted in 26/01/2015; divulged in 03/08/2015.

*Author for correspondence:

$\uparrow$ Master in Accounting (UFU)

Institution: Finances and Econometrics

Professor

Address: Av. João Naves de Avila, 2.121, -

Bloco F - Sala 1F216 -

Campus Santa Mônica - Uberlândia - MG

Brazil - CEP: 38.400-902

Email: mamede12@hotmail.com

Telephone: (034) 9192-2562
$\Omega$ Master in Accounting (UFU)

Institution: Accounting Professor

Address: Av. João Naves de Avila, 2.121

- Bloco F - Sala 1F253 -

Campus Santa Mônica - Uberlândia -

MG - Brazil - CEP: 38.400-902

Email: alessandra1909@hotmail.com

Telephone: (034) 9908-4867
$¥$ Doctor in Administration (FEA/USP)

Institution: Professor at the

Faculty of Business and

Management, Federal University

of Uberlândia (FAGEN/UFU)

Address: Av. João Naves de

Avila, 2.121, - Bloco F - Sala

1F216 -

Campus Santa Mônica -

Uberlândia - MG - Brazil

CEP: 38.400- 902

Email:pablo@fagen.ufu.br

Telephone: (034) 3239-4132
Doctor in Accounting (USP) Institution: Professor of the Graduate Program Stricto Sensu at the Federal

University of Uberlândia (FACIC/UFU)

Address. João Naves de Avila, 2.121 - Bloco F - Sala 1F253 -

Campus Santa Mônica -

Uberlândia - MG - Brazil

CEP: $38.400-902$

Email:gilbertojm@,facic.ufu.br Telephone: (034) 3239-4176

Note from the Editor: The article was accepted by Emerson Mainardes. 


\section{INTRODUCTION}

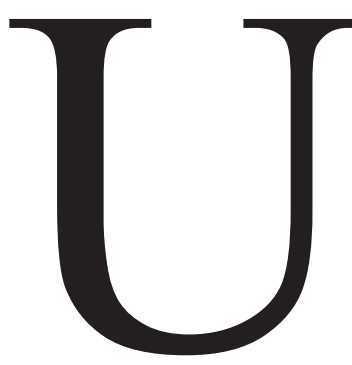

nderstanding the process of learning has always been important in all systems and educational programs, as it improves teaching techniques and educational policies. However a series of factors is linked to student performance, such as: faculty qualification, infrastructure of the educational institution, socio-demographic characteristics of students, student's personal factors and others (TINTO, 1975; MIRANDA, 2011; SANTOS, 2012; MIRANDA et al., 2013).

The student learning is related to their intentions with the university and preprofessional expectations defined, which are arising from the economic context in which it operates, as highlighted Tinto (1975). The author argues that the student goes through various interactions with the academic and social environment of the educational institution, which will result in redefining their academic commitments, and their professional goals.

Other studies have also sought to identify factors associated with student performance, such as early school life, performance, personality, work experience, demographic characteristics, psychological variables, among others (KOH; KOH, 1999; BAPTISTA; ALVES; SANTOS, 2008; CORNACHIONE JR. et al., 2010). Such research would seek justifications for differences in students learning and propose alternatives facilitators for the own learning process (CERQUEIRA, 2000).

Psychology researchers also have sought explanations for the school learning process, investigating the influence of the psychological variables on student performance: selfefficacy, which is among the factors that form the psychological mechanisms of student motivation (BANDURA, 1977); the locus of control, which, according to the theory of social learning, states that the students behavior is influenced by their own behavior, namely, "If the students believe that they control the outcome of their task, the more likely they will persist until it is executed" (RIBEIRO, 2000, p. 11).

Another psychological variable researched in academia is optimism, which has been linked to school performance. Studies show that optimist students believe and trust in their abilities, consequently they adapt better to the environment and have a better performance at school (BANDEIRA et al., 2002). Similarly, self-esteem has also been related to student performance. Studies show that self-confident students feel more competent, resulting in 
higher academic performance (BAUMEISTER et al., 2003; MARSH; O'MARA, 2008; PULLMAN; ALLIK, 2008; BATISTA; DELGADO, 2013).

The research mentioned above, regarding student performance, discuss about contending positions with respect to the main variables that influence, positively or negatively, the performance of pupils. However, the greatest provocation in this area is to identify the possible existence of relationships and impact of these variables, specifically the psychological, the performance of students of accounting sciences.

Given the above, the following research question arises: which variables are related to the performance of students of accounting in a Brazilian public university? For this purpose, we elected the Grade Point Average (GPA) as a measure of academic performance and as explanatory variables, the psychological scales of self-efficacy, self-esteem, optimism and locus of control, as well as two proxy variables of self-control: alcohol consumption and smoking habit. We also used four other control variables: gender, marital status, age and experience time in accounting.

The scenario of accounting education deserves attention of researchers for at least three reasons: (a) the expansion experienced in recent decades; (b) the changes in Brazilian Accounting by adopting international standards from 2008; (c) the low results obtained in performance evaluations conducted by the Instituto Nacional de Estudos e Pesquisas Educacionais Anísio Teixeira (INEP). According to data from the INEP (2007), the overall performance average of the area of accounting in national examination of students (ENADE) was 44.1 in the General Formation Component (ahead only of administration, 42.1) and 25.7 in the Specific Component (lowest general average), within a range of 0 to 100 .

Among the justifications of this study, we highlight the fact that studies were not found that associated behavioral variables in conjunction with socio-demographic variables to the performance of students of accounting in Brazil. In addition, the study also may help with the actors involved in the process of teaching and learning in accounting, in assisting directors, coordinators and teachers in planning pedagogical strategies best suited to the needs of students.

The work is structured in four sections besides this introduction. In the next section we present the literature review. The third details the methodology used in the research. Next, the analysis and discussion of the results is done. The last section presents the final considerations of the study. 


\section{LITERATURE REVIEW}

\subsection{STUDENT PERFORMANCE}

Research on student performance is abundant and points out that there are external and internal factors of the school unit correlated with excellence in student achievement. Some research (ALVES; CORRAR; SLOMSKI, 2004, MIRANDA, 2011) indicate that the variables: academic qualification of faculty, teachers with updated content, different teaching techniques, research activities, use of the book instead of handouts and abstracts and full access to microcomputers are positively associated with the performance of students in the accounting course.

Another important point highlighted in the performance of students was presented by Santos (2012, p. 193), to which it "the student performance is affected by the interaction between the characteristics of students, such as personal, socioeconomic factors, and the inputs of the educational institution". His research used the database organized by INEP, for examinations of the graduating students of accounting sciences in 2002, 2003 and 2006 (PROVÃO; ENADE, 2014).

Regarding the analysis of the variables that influence the behavior of students, Eikner and Montondon (2001) analyzed various aspects for 25 years to explain the student performance. They found that only three of them show significant for the performance of intermediate accounting course I being: grade point average in college, degree of utilization in the discipline of accounting theory and age of the student.

Behavioral variables also reflected in student performance, among them the motivation, aptitude for accounting, and type of learning have shown positive impact on student achievement, as anxiety reflects poorly on academic performance, as shown by Miranda et al. (2013). These results were obtained from the 39 items researched analysis that the variables that affect student performance. The authors classified the variables into three groups: faculty, student body and institutional variables. Have noted that variables related to the student body are the most researched and also those that best explain student performance, but the teacher and the institution of higher education, too, can play an important role. The authors point out that demographic variables are not the largest in the academic success of students, among them the variables positively related to performance are the socioeconomic situation and the 
number of children. Have factors such as absenteeism, hours of sleep, prior knowledge of the student and their expertise are cited as performance-related.

Results of a research conducted in a Spanish university with students of an accounting course revealed that the interest in accounting, the experience on the subject, the score in university entry examinations and self-confidence of the scholar were significantly correlated with their performance in the course (ARQUERO et al., 2009).

Seeking answers to the factors that affect the performance of students of accounting, Masasi (2012) conducted an empirical research at the Open University of Tanzania, with a sample of 122 students. The author examined the relationship between personal attributes (gender, labor, employment, marital status, children, elderly relatives) and the average overall performance. The results showed that students with children had good performance, the number of male students was greater than that of female students, and the performance of the men was higher than the women's.

It was also found that the practical experience in accounting related work is associated with the overall performance. In relation to the student's marital status, no association was detected with their overall performance, and there was a significant negative correlation between students who live with relatives and their performance. The author found an association between the age of the students and their performance, in that more mature people obtain greater results.

Contrary to the findings of Masasi (2012), the research of Seow, Pan and Tay (2011), performed in an accounting course at a Singapore university, found evidence that age is not significantly associated with successful academic performance. In addition, the authors observed that critical thinking, math aptitude and gender are significantly associated with the success of academic performance.

Some authors have also investigated the influence of drug use on school performance. Pasqualotto et al. (2002) contribute to the discussion, finding in their research conducted with students from the city of Santa Maria, Brazil, that the worst school performance is associated with the possibility of the student smoking. The authors found that students susceptible to smoking showed a below-average performance.

Studies on the effects of different patterns of alcohol consumption on school performance in adolescence in Portugal were developed by Fonseca (2010): the results show that moderate and occasional consumption does not bring any impact on academic 
performance. Warner (1998) and Donovan et al. (2004), also contribute to the discussion by arguing that the consumption of alcohol by young people influences their school performance.

As described above, the performance process is a complex topic, involving several variables and open paths to conduct research on several fronts. As professional accountants take on more and more an important role in the development of the economy, it is necessary to do research that tests the variables that influence accounting education and which consequently can bring improvements in the learning process.

\subsection{PSYCHOLOGICAL VARIABLES AND STUDENT PERFORMANCE}

Psychology researchers have sought explanations for disparities in the level of student performance. Avanci et al. (2007) point out in their research the importance of evaluating the student's self-esteem in the academic context, especially in situations of low school performance. According to the authors, the term self-esteem refers to the evaluation that the person makes of him or herself, expressing an attitude of approval or rejection. Self-esteem is the personal value judgment revealed in attitudes that an individual has within himself and evaluated as: low, medium and high. Also according to Avanci et al., (2007), low self-esteem is characterized by the feeling of incompetence, lack of aptness for life and inability to overcome challenges.

It also emphasize the studies that linked the self-esteem and academic performance of students, as highlighted Baumeister et al., (2003), Marsh and O'Mara (2008) Pullman and Allik (2008). They found that efforts to enhance the self-esteem of the students did not improve their academic performance. In this context, the first research hypothesis appears:

$\mathbf{H}_{1}$ : self-esteem affects positively the performance results of the accounting students of the sample.

Optimism has also been the subject of research in academic performance. Bandeira et al. (2002) conducted an investigation with 396 students, with an average age of 22.34 years. It was found that a low level of optimism influences the students' adaptation to the university environment, and causes lower academic performance. Smith and Hoy (2007) also found influence of optimism in student performance through a survey conducted with 99 Texas elementary schools. From these findings, the second research hypothesis appears:

$\mathbf{H}_{2}$ : optimism affects positively the performance results of the accounting students of the sample. 
As argued Bandeira et al., (2002) argues, past situations or events influence the expectations regarding future events. The attribution that negative events have internal, stable and global causes would be related to a pessimistic tendency. Thus, it should be noted that optimism correlates with measures of other corresponding concepts, such as self-esteem, locus of control and self-efficacy (BANDEIRA et al., 2002).

Flowers, Milner and Moore (2003) investigated the impact of locus of control on the academic results of students in Africa. The results show that students with higher levels of locus of control were more likely to have higher educational aspirations than students with lower levels of locus of control. Ross and Broh (2000) also researched about the influence of locus of control over student achievement, and concluded that the sense of personal control affects academic performance. With that, the third research hypothesis appears:

$\mathbf{H}_{3}$ : an internal locus of control affects positively the performance of accounting students of while an external locus of control affects negatively the performance of the accounting students of the sample.

The rationale for this hypothesis is that, according to Rogers-Silva (2011), individuals with a higher degree of internal locus of control have the perception of being more responsible for the day-to-day events around them, and individuals with a higher degree of external locus of control have the perception that they have little influence over the everyday events around them.

Already the research evidenced by Teixeira (2008) examined the association between the variable self-efficacy and academic performance of students of the University of Lisbon. The results show that the construct of self-efficacy is strongly related to school and social learning. Oliveira and Soares (2011) also investigated the relationship between self-efficacy variable with the performance of elementary school students from two private schools in the city of Rio de Janeiro. The results show that this variable predicts student performance.

According to Zimmerman (2000) self-efficacy has emerged as an effective predictor of students' learning. This construct has shown to be sensitive to the improvements in the methods of learning and the prediction of student performance results. Bong and Skaalvik (2003) argue that positive perceptions of self-efficacy generate many desirable results, leading students to develop attainable and challenging academic goals for themselves. These students feel less anxious in the context of accomplishment, feel more pleasure in their scholarly work, persist longer in difficult tasks and feel better as a person and as a student in general. 
The study of self-efficacy seeks primarily to understand the power in the belief of the individual regarding his personal skills that enable him to handle a variety of situations and his ability to perform multiple tasks in different contexts (MEDEIROS, 2006). From these findings, the fourth research hypothesis appears:

H4: self-efficacy has a positive influence on the performance of accounting students of the sample.

The studies highlighted by Cruz (2006) studied other behavioral variables and argues that self-control can be the explanation for problems of individuals and society, such as: violence, drug use, the preservation of the environment among others. The author argues that self-control shows itself as an important tool in solving behavioral problems involving both the interests of individuals and of the group in which they are inserted.

Epstein (1997) analyzed subjects without any behavioral repertoire of self-control, and found that these people are totally controlled by the environmental stimuli that surround them, generating compulsive behavior of eating, smoking, drinking alcoholic beverages among others. On the other hand, individuals with a repertoire of self-control change the environmental variables that affect their behavior, and are thus controlled by delayed consequences of events, like studying to do well on exams.

So when the student receives an invitation from friends to go to a bar, he can have two behaviors. In the one hand, he can act without thinking and go to the bar with his friends and enjoy the pleasure of their company, music and drink, even if that brings consequences like losing points for an assignment or missing an important class. Or on the other hand, he can reflect on the future consequences that this attitude can bring, such as missing class content, being penalized in scoring, having absences in the curriculum, etc. at which point self-control comes in, which repels the invitation of the friends (CRUZ, 2006). Given this context, the fifth research hypothesis appears:

H5: $_{5}$ self-control is associated positively to the performance of accounting students of the sample.

\section{METHODOLOGICAL ASPECTS}

In light of the objectives of the research, we decided to carry out a descriptive study from a quantitative approach, assuming the construction of the hypotheses, which are tested through statistical treatment. The focus of the model will be to analyze if there is a 
relationship between the Grade Point Average (GPA) of the students and some of the sociodemographic and psychological variables discussed in the literature review.

\subsection{SAMPLE}

To perform our research, we created a sample with students enrolled from the second period of the undergraduate program in accounting from a public Brazilian university, since students of the first period still have no GPA. Questionnaires with valid replies totaled 494 individuals, representing approximately $49 \%$ of the students enrolled in the course. Students were approached to answer the questionnaire under the most absolute confidentiality of the information.

\subsection{DATA COLLECTION}

The data collection instrument sought information about the social and economic behavior of the students in the undergraduate program in accounting, to later relate it to their GPA. In the first part of the questionnaire, we collected the registration number of the student. The second part has the questions, separated according to psychological scales: self-efficacy, locus of control, self-esteem and optimism. The other variables are: sex, marital status, age and smoking habits and alcohol consumption as proxies of self-control.

The questionnaire was pre-tested with 13 students of the master's course in accounting of the institution researched, in which participants suggested improvements in the research tool. Thus, the structure of the scales in relation to the items of the questionnaires of the four constructs was divided as follows: the self-efficacy construct in this model was used through the General Self-Efficacy Scale, developed by Schwarzer (1992). This scale was validated by Nunes et al. (1999) and used by Medeiros (2006) in the context of learning in business administration. The scale of Locus of control was based on Levenson (1973), due to its simplicity (small number of items) and generality (DELTA COLETA; DELTA COLETA, 1997).

For the construction of the optimism variable, we used the Life Orientation Test (LOT), originally proposed by Scheier, Carver and Bridges (1994) and validated in Brazil by Bandeira et al., (2002). The LOT measures "the construct of life orientation, referring to the way people perceive their lives, more optimistically or less optimistically" (BANDEIRA et al., 2002, p. 252). The Rosenberg self-esteem scale (1956/1989) was selected to construct the self-esteem variable because it is one of the most widely used instruments for the assessment 
of global self-esteem (MARTIN-ALBO et al., 2007) and was nationally validated by the work of Avanci et al. (2007).

We used Cronbach's alpha $(\alpha)$ to estimate the reliability of psychological scales of the questionnaire applied in the research. According to Hora, Monteiro and Arica (2010), the $\alpha$ coefficients must deliver results greater than 0.60 to be deemed accepted.

\subsection{EMPIRICAL MODEL}

The data found in the answers to the questionnaires are confronted with the GPA results for verification of associations between the socio-demographic and psychological variables investigated and the academic performance of students. A resolution of the board of undergraduate studies at the university determines that the GPA must be held at the end of each term. The formula for calculating the GPA encompasses grades, the attended course load, the enrolled course load and the course load in curricular components with reprobation by attendance.

The students' GPAs were provided by the course coordination. In this research, we analyzed the performance of individual classes (from the 2 nd to the 10 th period), because the calculation of the coefficient is done cumulatively in relation to prior periods. The empirical model used in this research, which includes the association between the GPA and the explanatory variables, is represented in the equation below:

$$
y=\beta_{0}+\beta_{1} x_{1}+\beta_{2} x_{2}+\ldots+\beta_{p} x_{p}+\varepsilon
$$

Where $y$ represents the dependent variable GPA; $x_{1}, x_{2}, \ldots, x_{p}$ represent the independent variables self-efficacy, internal locus of control, chance, power, optimism, high self-esteem, low self-esteem, alcohol consumption, drug abuse, tobacco, sex, age, marital status and time of experience in accounting; $\beta_{0}, \beta_{1}, \beta_{2}, \ldots, \beta_{p}$ represent the parameters and $\varepsilon$ is the error term, characterized by a random variable which follows the assumptions of the normal model of classic linear regression (GUJARATI; PORTER, 2011).

\section{ANALYSES OF THE RESULTS}

All the psychological scales, except internal locus of control, presented Cronbach's Alphas greater than 0.60 , which was the reason why that scale was not part in the construction of the empirical model. Table 1 presents the descriptive statistics for the psychological variables of the model and for the GPAs of students. It should be noted that we adopted the same procedure of allocation of values lost in the psychological scales as Rogers-Silva 
(2011), i.e. to fill the value lost in each question of the scale from the regression of that question against the other questions of the psychological scale. In General, lost data did not show potential for problems, since it did not total more than $2 \%$ of the database. The other control variables had no data lost.

Table 1 - Descriptive Statistics of Psychological Scales and the CRA ( $=494)$

\begin{tabular}{lcccc}
\hline & Average & $\begin{array}{c}\text { Standard } \\
\text { deviation }\end{array}$ & Minimum & Maximum \\
\cline { 2 - 5 } Self-Efficacy & 29,51 & 4,22 & 14 & 40 \\
Optimism & 16,74 & 3,68 & 4 & 24 \\
High self-esteem & 15,68 & 2,51 & 5 & 20 \\
Low self-esteem & 15,30 & 2,99 & 5 & 20 \\
Power & 18,97 & 4,13 & 11 & 37 \\
Chance & 19,50 & 4,19 & 10 & 33 \\
\hline CRA & 70,10 & 14,28 & 15.47 & 95.04 \\
\hline
\end{tabular}

Note: Self-efficacy scale based on Schwarzer (1992); Scale of optimism based on the Life Orientation Test (LOT) of Scheier et al. (1994); Self-esteem scale, with two subscales (low self-esteem and high self-esteem) based on Rosenberg (1956/1989); Power and chance are the subscales of the locus of control scale of Levenson (1973), which measure the external locus of control construct; GPA = Grade Point Average. Source: Prepared by the authors

The students' GPA shows that, on average, students have a performance of $70.10 \%$. This median performance can be justified by the lack of practical experience in accounting, because $65.44 \%$ (table 2) of the respondents said they did not have experience in the accounting area. This is in line with the research of Arquero et al., (2009), who found correlation between performance and experience. In table 2, we presented the results of the descriptive statistics of the socio-demographic variables and of two proxies of self-control.

Table 2 - Descriptive Statistics of Socio-Demographic Variables and Proxies of Self-Control $(\mathrm{N}=494)$

\begin{tabular}{lcc} 
& Comments & Frequency Percentage \\
\cline { 2 - 3 } Female & 216 & $43,72 \%$ \\
Male & 278 & $56,28 \%$ \\
\hline Single & 442 & $89,47 \%$ \\
Married & 50 & $10,12 \%$ \\
Divorced & 2 & $0,40 \%$ \\
\hline Smoker & 14 & $2,83 \%$ \\
Non-smoker & 480 & $97,17 \%$ \\
\hline Does not consume alcoholic beverages & 267 & $54,71 \%$ \\
Consumes alcoholic beverages on weekends & 200 & $40,98 \%$
\end{tabular}


Consumes alcoholic beverages three times a week

$21 \quad 4,30 \%$

\begin{tabular}{lcc}
\hline Time of experience - zero & 320 & $65,44 \%$ \\
Time of experience - less than a year & 66 & $13,50 \%$ \\
Time of experience - from one to two years & 50 & $10,22 \%$ \\
Time of experience - from two to three years & 28 & $5,73 \%$ \\
Time of experience - from three to four years & 10 & $2,04 \%$ \\
Time of experience - over four years & 15 & $3,07 \%$ \\
\hline Age under 20 years & 125 & $25,30 \%$ \\
Age between 20 to 30 years & 339 & $68,62 \%$ \\
Age between 30 to 40 years & 24 & $4,86 \%$ \\
Age greater than 40 years & 6 & $1,21 \%$ \\
\hline
\end{tabular}

Source: Prepared by the authors

By means of the statistics presented in table 2, it becomes possible to characterize the accounting course students that were part of the sample: the majority (56.28\%) is male, corroborating the studies of Masasi (2012); 68.04\% are between the ages of 20 and 30 years; $89.47 \%$ of the respondents are single, only $2.89 \%$ have the habit of smoking, and $45.28 \%$ responded that they consume alcoholic beverages, which shows that alcohol consumption is greater than cigarette consumption among these students. Of the total number of people who said they consume alcoholic beverages, $40.98 \%$ drink only on weekends.

Table 3 presents the matrix of correlation coefficients of Spearman between the psychological scales of the model and the GPA. It turns out that no pair of variables presents a high correlation to the point of causing a problem of multicollinearity, because the coefficients presented are below 0.80 in module, as a practical rule presented by Gujarati and Porter (2011).

Table 3 - Correlation Coefficient of Spearman Between the Psychological Scales and the GPA $(\mathbf{N}=494)$

\begin{tabular}{|c|c|c|c|c|c|c|c|}
\hline & GPA & Self-Efficacy & Power & Chance & Optimism & $\begin{array}{c}\text { Low self- } \\
\text { esteem }\end{array}$ & $\begin{array}{c}\text { High self- } \\
\text { esteem }\end{array}$ \\
\hline GPA & 1.00 & & & & & & \\
\hline Self-Efficacy & -0.04 & 1.00 & & & & & \\
\hline Power & -0.02 & -0.09 & 1.00 & & & & \\
\hline Chance & $-0.11^{*}$ & $-0.11^{*}$ & $0.48^{*}$ & 1.00 & & & \\
\hline Optimism & 0.06 & $0.28 *$ & $-0.13 *$ & $-0.21 *$ & 1.00 & & \\
\hline Low self-esteem & 0.03 & $0.31 *$ & $-0.23 *$ & $-0.28^{*}$ & $0.40 *$ & 1.00 & \\
\hline High self-esteem & 0.04 & $0.37 *$ & $-0.13^{*}$ & $-0.18^{*}$ & $0.33 *$ & $0.58 *$ & 1.00 \\
\hline
\end{tabular}

Source: prepared by the authors 
To estimate the final model, we used the sample without outliers $(\mathrm{N}=457)$. For exclusion of outliers we adopted the dfits statistic calculations for each standardized residue and we used the cut-off points suggested by Baum (2006), whose criterion resides in excluding observations with $\mid$ difts $\mid>2(\mathrm{k} / \mathrm{N})^{1 / 2}$, where $\mathrm{k}=$ number of parameters in the model, and $\mathrm{N}=$ number of observations.

Table 4 provides the results and the robustness of the proposed model: 1) the calculation of the variance inflation factor (VIF) for each variable verified the absence of multicollinearity problems (VIF $<10$ ), as well as in the analysis of individual correlations; 2) the Breusch-Pagan-Godfrey test presented no significant result, therefore proving the absence of heteroscedasticity in the residues (chi2=1.58; p-value=0.20); and 3) the Ramsey RESET test did not reject the model specification $(\mathrm{F}=0.11$; $\mathrm{p}$-value $=0.95)$, besides the $F$ statistics corroborating that the model as a whole is significant at the level of $1 \%$.

Of the psychological variables investigated, only power and chance, which refer to the external locus of control, show an association with student performance, the first having a significance level of $5 \%$, and the second a significance level of $1 \%$. Corroborating the studies of Ross and Broh (2000), which found that the sense of personal control affects academic performance.

The results for the variable Power, show that students with the belief that they are powerful and are in control, get higher grades when compared to other students. Cornachione et al., (2010) found that the students themselves attribute successful performance to their own effort.

Table 4 - Determining Factors for the Academic Performance of Students in the Accounting Course $(\mathrm{N}=457)$

\begin{tabular}{|c|c|c|c|c|}
\hline \multirow{8}{*}{$\begin{array}{c}\text { Psychological } \\
\text { Variables }\end{array}$} & & $\begin{array}{l}\text { Estimated } \\
\text { coefficients }\end{array}$ & T-Statistic & VIF \\
\hline & Intercept & 73.10 & $10.34^{* * *}$ & - \\
\hline & Self-Efficacy & -0.01 & -0.06 & 1.34 \\
\hline & Power & 0.28 & $1.71^{* *}$ & 1.45 \\
\hline & Chance & -0.42 & $-2.53^{* * *}$ & 1.52 \\
\hline & Optimism & 0.14 & 0.81 & 1.32 \\
\hline & Low self-esteem & 0.11 & 0.44 & 1.74 \\
\hline & High self-esteem & 0.02 & 0.06 & 1.74 \\
\hline Sex & Female & 2.05 & $1.65^{*}$ & 1.18 \\
\hline
\end{tabular}




\begin{tabular}{clccc}
\hline \multirow{3}{*}{ Marital status } & Divorced & -10.54 & -1.20 & 1.07 \\
& Single & -1.14 & -0.49 & 1.39 \\
\cline { 2 - 5 } Alcohol consumption habit & Yes & -7.20 & $-1.82^{*}$ & 1.07 \\
\cline { 2 - 5 } Age & Yes & -1.63 & -1.49 & 1.19 \\
\cline { 2 - 5 } & Between 20 and 30 years & -2.82 & $-2.09^{* *}$ & 1.21 \\
& Between 30 and 40 years & -6.12 & $-1.75^{*}$ & 1.40 \\
& More than 40 years & -2.00 & -0.27 & 1.12 \\
\cline { 2 - 5 } Experience time in & Less than a year & -1.36 & -0.79 & 1.09 \\
accounting area & From one to two years & 0.03 & 0.02 & 1.08 \\
& From two to three years & 6.57 & $2.57^{* * *}$ & 1.07 \\
& From three to four years & 4.39 & 1.06 & 1.05 \\
& More than four years & 0.21 & 0.06 & 1.09
\end{tabular}

$\mathrm{F}=2.14^{* * *}$

$\mathrm{R}^{2}=0.08$

BPG test $($ chi2 $)=1.58$

Test RESET $(F)=0.11$

Note: Statistical significance: $* * * 1 \%, 5 \%, *$ and $* 10 \%$; The categories of alcoholic consumption on weekends and three times a week were aggregated into a single category: alcohol consumption; VIF = variance inflation factor; BPG test represents the Chi-square test statistic of heteroscedasticity of Breusch-Pagan-Godfrey; RESET test represents the F statistic of the Ramsey specification test.

Source: prepared by the authors

The Chance variable shows that students who believe that their lives are controlled by chance, luck, or fate have a lower academic performance when compared to other students without this feature, showing that the student must study to have good performance, and not just believe in luck or fate. This finding is in line with Cornachione et al., (2010), i.e. higher frequency of external causes is related to lower performance. In view of the results of the variables Chance and Power, we do not partially reject hypothesis $\mathbf{H}_{3}$, an external locus of control affects negatively the performance of the accounting students of the sample, since it was possible to assess the impact of the internal locus of control.

We also did not find an association between psychological scale self-esteem (low selfesteem and high self-esteem) with the performance of the students. The results of this research are justified by the studies of Baumeister et al. (2003), Marsh and O'Mara (2008) and Pullman and Allik (2008). All these authors found that high self-esteem does not necessarily lead to a good performance. Therefore we reject hypothesis $\mathbf{H}_{1}$ : self-esteem affects positively the performance results of the accounting students of the sample. 
There was no association between optimism and the performance of the accounting students, contradicting studies of Bandeira et al. (2002) and Smith and Hoy (2007). These contradictions in the results of the research show that the subject deserves to be discussed and investigated empirically in other contexts. Thus, we reject hypothesis $\mathbf{H}_{2}$ : optimism affects positively the performance results of the accounting students of the sample.

Another variable considered in the academic context was the self-efficacy. The research of Zimmerman (2000), Bong and Skaalvik (2003), Teixeira (2008), Oliveira and Soares (2011), show that this variable is an effective predictor of students' learning, and is strongly related to the school and social learning. However this research found no association between self-efficacy and the performance of the accounting students. Therefore, we reject hypothesis $\mathbf{H}_{4}$ : self-efficacy has a positive influence on the performance of accounting students of the sample.

Despite the insignificant findings for the scales of self-esteem, self-efficacy and optimism, it should be noted that these constructs are very related to each other, as Bandeira et al., (2002) point out. Consequently, the scale of external locus of control, significant in the final model, might be picking up information from the other scales: the significant correlations between the scales in table 3 highlight this fact.

While exploring other variables that impact student performance, we found that the sex of the student, an age between 20 and 40 years, time of experience in accounting and smoking habits are statistically associated with the GPA of the students. In relation to the age group, the results show that students between 20 and 40 years old have a lower academic performance than other students. These findings confirm the theory of Eikner and Montondon (2001) and Masasi (2012), that maturity allows older students to have greater concentration and better manage their time, achieving greater success in the accounting area.

For Experience Time in accounting, the findings show that only the time between two and three years has statistical significance, namely, students with this experience time feature an academic performance 6.57 points higher than other students of the accounting course from the university studied in this research, corroborating the findings of Masasi (2012).

The result for the variable Smoking shows that there is a significant negative association with the GPA, confirming the finding of Pasqualotto et al. (2002). Smokers have a performance 7.20 points lower when compared to students who do not smoke. A justification for this lower performance can be related to individuals without self-control, which, according 
to Epstein (1997) and Cruz (2006), can lead to compulsive behavior such as drug use and low performance.

Aspects related to alcohol consumption show that this trait is not associated with the student's performance, contrary to the findings of Warner (1998) and Donovan et al. (2004). One possible explanation for this fact may be related to the frequency of alcohol use among those students: Fonseca (2010) argues that occasional consumption does not impact student performance. Most of the consumer students stated that they consume alcoholic beverages only on weekends. In view of those results for smoking habits and alcohol consumption, we do not reject hypothesis $\mathbf{H}_{5}$ : self-control is associated positively to the performance of accounting students of the sample.

As for the sex of the students, the results show that women of the accounting course have better academic performance than men, as opposed to the findings of Masasi (2012) who found that the performance of men is better than that of women. Marital status was not statistically significant to justify the academic performance of students, confirming the search results of Masasi (2012).

Table 5 shows alcohol consumption data, sorted by age and sex of the respondents of the survey.

Table 5 - Alcohol Consumption, Smoking, Age and Sex Data

\begin{tabular}{lcccccc}
\hline & \multicolumn{2}{c}{ Sex } & \multicolumn{3}{c}{ Age group-in years } \\
\cline { 2 - 7 } & Female & Male & $<\mathbf{2 0}$ & $\mathbf{2 0 - 3 0}$ & $\mathbf{3 0 - 4 0}$ & $>\mathbf{4 0}$ \\
\cline { 2 - 7 } Alcohol - non-consumer & 86 & 181 & 79 & 173 & 12 & 3 \\
Alcohol - weekends & 89 & 111 & 40 & 147 & 11 & 2 \\
Alcohol - 3x per week & 5 & 16 & 2 & 18 & 0 & 1 \\
\hline Smoker & 1 & 13 & 3 & 11 & 24 & 6 \\
Non-Smoker & 277 & 203 & 122 & 328 & 0 & 0 \\
\hline
\end{tabular}

Source: prepared by the authors

Despite the consumption of alcoholic beverages not being related to student performance in the accounting course, it deserves the attention of society. Most of the smokers of the research sample are young people under 30 years old and male, as shown in Table 5. The same scenario exists for the consumption of alcoholic beverages. $45.25 \%$ of these young people consume alcohol. Among them, male students represent $57.47 \%$, and most of these consumers (93.67\%) are under the age of 30 years.

\section{FINAL CONSIDERATIONS}


The objective of this research was to investigate the influence of psychological variables on the performance of students of accounting sciences in a Brazilian public university. Despite the extensive range of studies investigating the student performance, there are still doubts and controversies about which aspects have a positive or negative influence on the performance of pupils. In addition, no studies were found that investigated the impact of psychological variables on the performance of students of accounting, which are future professionals who have a prominent role in the economic environment as responsible for the information for decision-making of economic agents.

The empirical model used was a multiple linear regression, estimated via Ordinary Least Squares (OLS), whose assumptions were tested in order to assess the association between student performance the accountancy course and the variables: gender, marital status, habits smoking, alcohol consumption, age, length of experience in accounting, self-efficacy, optimism, self-esteem and locus of control.

As an additional contribution to the literature, were found possible influences of smoking habits, gender, age, length of experience in accounting and construct locus of external control over the performance of students of accounting sample sciences. In addition, the results of this research have practical implications for the development of strategies to improve the academic performance of these students, helping directors, coordinators and teachers in planning activities focused on variables that influence student performance.

Considering the current scenario, marked by the expansion of higher education in Brazil today, the changes in Brazilian Accounting with the adoption of international standards from 2008 and the poor results obtained in the performance assessments conducted nationwide, the results calculated can direct the construction of pedagogical projects in the accounting area, support the construction of educational policies, both by the professional class as by the government and higher education institutions. But mostly, can help the students themselves to know the limits identified to enlarge their performances.

With the main results it appears that among the legal drugs most consumed in Brazil (alcohol and tobacco), only the tobacco impact on attainment. Despite the alcohol consumption did not yield statistically significant results, to infer about the negative effects on school life of students, the number of young people under 30 who are consumers deserve attention from society: $93.67 \%$ of the 221 respondents who said consumers of alcoholic drinks are young people under 30 years. As you know, this addiction sets in slowly. Therefore, it is expected that the drop in income may occur in future times. 
In terms of age, the age between 20 and 40 years is negatively associated with student achievement, that is, the tendency is that the greater the age, the lower the academic performance of the student in accounting sciences. And the time variable experience in accounting shows that the time of two to three years of experience with the accounting practice is positively related to academic performance of students in accounting sciences. One possible explanation for this effect lies in the argument that the application of accounting concepts and techniques, over time experience, can help the student in the learning process and setting the concepts learned in the classroom.

Analyzing the results of the psychological scales, just the construct external locus of control (power and chance) showed statistical significance, showing that the belief of being in control, i.e. they are powerful people, is positively linked to student performance. The findings suggest that the belief in chance, luck or fate is negatively related to the student's performance. The other variables: self-efficacy, optimism, internal locus of control, high selfesteem and low self-esteem are not related to performance of the accounting course students studied in this research.

Regarding marital status was not statistically significant, that is, to this database, one can not infer any association with the performance of the accounting student. The results also show that women have higher academic performance than men.

Analyzing the results of psychological scales, only the construct locus of external control (power and chance) statistically significant, showing that the control belief by powerful people is positively associated with student performance. This belief pervades the fact that people who have significant influence over the other, tend over the academic years, having higher performance.

The findings also show that the belief in chance, luck or fate is negatively related to student performance. In other words, the fact believe that chance and / or destination are lucky as only the success of providers, influences contrary to academic performance.

The other variables, self-efficacy, optimism, internal locus of control, high self-esteem and low self-esteem were not related to student performance of students of accounting object of study sciences.

One limitation of this study was to apply the questionnaires to the students who were present in the classroom, and so do not know the pattern of behavioral variables of absent students. As described by the literature students with psychological problems and abuse of 
drugs have difficulties to honor its obligations, it is possible that many of them were among the missing.

A second limitation in this research lies in the fact that the sample was based only on an educational institution. Finally, it stands out the limitation that only a few were analyzed demographic and psychological variables.

It is suggested as future research a study of the variables that impact the academic achievement of students in business courses: Administration, Accounting, and Economics, as are related areas. Comparing the results between courses to check the psychological aspects that are associated with the output of each of these courses.

\section{REFERENCES}

ALVES, C. V.; O, CORRAR, L.; J, SLOMSKI, V. A docência e o desempenho dos estudantes dos cursos de graduação em contabilidade no Brasil. In: CONGRESSO USP DE CONTROLADORIA E CONTABILIDADE, 4., 2004, São Paulo (SP). Anais... São Paulo: FEA/USP, 2004.

ARQUERO, J. L.; BYRNE, M.; FLOOD, B.; GONZALEZ, J. M. Motives, expectations, preparedness and academic performance: a study of students of accounting at a Spanish University. Revista de Contabilidad-Spanish Accounting Review, v. 12, n. 2, p. 279-300, 2009.

AVANCI, J. Q.; ASSIS, S. G.; SANTOS, N. C.; OLIVEIRA, R. V. C. Adaptação transcultural de Escala de Auto-estima para adolescentes. Psicologia: Reflexão e Crítica, v. 20, n. 3, p. 397-405, 2007.

BANDEIRA, M.; BEKOU, V.; LOTT, K. S.; TEIXEIRA, M. A.; ROCHA, S. S. Validação transcultural do Teste de Orientação da Vida. Estudos de Psicologia, v. 7, n. 2, p. 251-258, 2002.

BANDURA, A. Social learning theory. Englewood Cliffs, N.J.: Prentice-Hall, 1977.

BATISTA, M.; DELGADO, S. C. A prática de judo em relação com o autoconceito, a autoestima e o rendimento escolar de alunos do primeiro ciclo do ensino básico. Revista de Ciencias del Deporte, v. 9, n. 3, p. 193-210, 2013.

BAPTISTA, M. N.; ALVES, G. A. S.; SANTOS, T. M. M. Suporte familiar, auto-eficácia e lócus de controle evidências de validade entre os construtos. Psicologia Ciência e Profissão, v. 28, n. 2, p. 260-271, 2008.

BAUM, C.F. An introduction to modern econometrics using Stata. Stata Press College Station, USA, 2006.

BAUMEISTER, R. F. et al. Does high self-esteem cause better performance, interpersonal success, happiness, or healthier lifestyles? Psychological Science in the Public Interest, v. 4, p. 1-44, 2003. 
BONG, M.; SKAALVIK, E. M. Academic self-concept and self-efficacy: How different are they really? Educational Psychology Review, v. 15, n. 1, p. 1-40, 2003.

CERQUEIRA, T. C. S. Estilos de aprendizagem em universitários. 2000. Tese (Doutorado em Educação) - Programa de Pós-Graduação em Educação, Faculdade de Educação, Universidade Estadual de Campinas, Campinas (SP), 2000.

CORNACHIONE JR. E. B. et al. O bom é meu, o ruim é seu: perspectivas da teoria da atribuição sobre o desempenho acadêmico de alunos da graduação em Ciências Contábeis. Revista Contabilidade e Finanças, v. 21, n. 53, p. 1-24, 2010.

CRUZ, R. N. Uma introdução ao conceito de autocontrole proposto pela análise do comportamento. Revista Brasileira de Terapia Comportamental e Cognitiva, v. 8, n.1, p. $1-9,2006$.

DELA COLETA, M. F.; DELA COLETA, J. A. Estudos sobre o lócus de controle: uma amostra da pesquisa brasileira no período 1979-1995. Cadernos de Psicologia, n. 1, p. 135$141,1997$.

DONOVAN, J. E. et al. Really underage drinkers: alcohol use among elementary students.

Alcoholism: Clinical and Experimental Research, v. 28, n. 2, p. 341-349, 2004.

EIKNER, A. E.; MONTONDON, L. Evidence on factors associated with success in intermediate accounting I. Accounting Educators Journal, v. 13, 2001.

EPSTEIN, R. Skinner as self-manager. Journal of Applied Behavior Analysis, v. 30, n. 3, p. 545-568, 1997,

FLOWERS, L. A.; MILNER, H. R.; MOORE, J. L. Effects of locus control on African American high school seniors' educational aspirations. The High School Journal, v. 87, n. 1, p. 39-50, 2003.

FONSECA, A. C. Consumo de álcool e seus efeitos no desempenho escolar. Revista Portuguesa de Pedagogia, v. 44, n. 1, p 259-279, 2010.

GUJARATI, D.; PORTER, D. C. Econometria básica. 5. ed. Porto Alegre: McGraw Hill, 2011.

HORA, H. R. M.; MONTEIRO, G. T. R.; ARICA, J. Confiabilidade em questionários para qualidade: um estudo com o coeficiente Alfa de Cronbach. Produto \& Produção, v. 11, n. 2, p. $85-103,2010$.

$\mathrm{KOH}, \mathrm{M}$. Y.; KOH, H. C. The determinants of performance in an accountancy degree programme. Accounting Education, v. 8, n. 1, p. 13-29, 1999.

LEVENSON, H. Multidimensional locus of control in psychiatric patients. Journal of Consulting and Clinical Psychology, v. 41, p. 397-404, 1973.

MARSH, H. W.; O'MARA, A. Reciprocal effects between academic self-concept, selfesteem, achievement, and attainment over seven adolescent years. Personality and Social Psychology Bulletin, v. 34, n. 4, p. 542-552, 2008. 
MARTIN-ALBO, J. et al. The Rosenberg self-esteem scale: translation and validation in university students. The Spanish Journal of Psychology. v. 10, n. 2, p.458-467, 2007.

MASASI, N. J. How personal attribute affect students' performance in undergraduate accounting course. A case of adult learner in Tanzania. International Journal of Academic Research in Accounting, Finance and Management Sciences, v. 2, n. 2, p. 201-211, 2012.

MIRANDA, G. J. Relações entre as qualificações do professor e o desempenho discente nos cursos de graduação em Contabilidade no Brasil. 2011. Tese (Doutorado em Ciências Contábeis) - Programa de Pós- Graduação em Ciências Contábeis, Departamento de Contabilidade e Atuária (FEA/USP), São Paulo (SP), 2011.

MIRANDA, G. J. et al. Determinantes do desempenho acadêmico na área de negócios. In: ENCONTRO DE ENSINO E PESQUISA EM ADMINISTRAÇÃO E CONTABILIDADE(ENEPQ), 7., 2013, Brasília (DF). Anais... Brasília: ANPAD, 2013. Disponível em: $<\mathrm{http}$ ://www.anpad.org.br/evento.php?acao=trabalhoandcod_edicao_subsecao $=989$ andcod_ev ento_edicao=70andcod_edicao_trabalho=16665>. Acesso em: 14 out. 2013.

MEDEIROS, A. L. B. Alfabetismo funcional em alunos do curso de Administração de Empresas e sua relação com a auto-eficácia e o auto-controle de suas atividades de aprendizagem. São Paulo, 2006. Dissertação (Mestrado) - Programa de Pós-Graduação do Centro Universitário Nove de Julho, São Paulo (SP), 2006.

NUNES, $R$ et al. A escala de auto-eficácia geral percepcionada. 1999. Disponível em $<$ http://web.fuberlin.de/skalen/Language_Selection/Portuguese/AutoEficacia_Geral_Percepci on/hauptteil_auto-eficacia_geral_perception.htm>.

OLIVEIRA, M. B.; SOARES, A. B. Auto-eficácia, raciocínio verbal e desempenho escolar em estudantes. Psicologia: Teoria e Pesquisa, v. 27, n. 1, p. 33-39, 2011.

PASQUALOTTO, A. C. et al. A relação entre o adolescente e o tabaco: estudo de fatores sóciodemográficos de escolares em Santa Maria, RS. Pediatria, v. 24, p. 11-16, 2002.

PULLMANN, H.; ALLIK, J. Relations of academic and general self-esteem to school achievement. Personality and Individual Differences, v. 45, n. 6, p. 559-564, 2008.

RIBEIRO, C. Em torno do conceito de lócus de controlo. Coimbra University Press, p. 297$314,2000$.

ROGERS SILVA, P. Psicologia do risco do crédito: análise da contribuição de variáveis psicológicas em modelos de credit scoring. 2011. 232 f. Tese (Doutorado) - Curso de Administração, Faculdade de Economia, Administração e Contabilidade, Universidade de São Paulo, São Paulo, 2011.

ROSENBERG, M. Society and the adolescent self-image. Princeton, NJ: Princeton University Press, 1989.

ROSS, C. E.; BROH, B. A. The roles of self-esteem and the sense of personal control in the academic achievement process. Sociology of Education, p. 270-284, 2000.

SANTOS, N. A. Determinantes do desempenho acadêmico dos alunos dos cursos de Ciências Contábeis. 2012. Tese (Doutorado em Ciências Contábeis) - Programa de Pós 
Graduação em Ciências Contábeis, Departamento de Contabilidade e Atuária, FEA/USP, São Paulo, 2012.

SCHEIER, M. F.; CARVER, C. S.; BRIDGES, M. W. Distinguishing optimism from neuroticism (and trait anxiety, self- mastery, and self-esteem): a reevaluation of the Life Orientation Test. Journal of Personality and Social Psychology, v. 67, v. 6, p. 1063-1078, 1994.

SCHWARZER, R. Self-efficacy as a resource factor in stress appraisal processes. In: (Ed.). Self-efficacy: thought control of action. Washington, DC: Hemisphere, 1992. P. 195213. Disponível em: $<$ http://chipts.ucla.edu/assessment/Assessment_Instruments/Assessment pdf_new/assess_gses_pdf.pdf>. Acesso em: 06 jul. 2010.

SEOW, P. S.; PAN, G.; TAY, J. In search of a different accounting graduate: entrypoint determinants of students' performance in an undergraduate accountancy degree programme in Singapore. In: EUROPEAN ACCOUNTING ASSOCIATION CONFERENCE, 2011, Roma (ITA). Anais... Roma: EAA, 2011. p. 9-11.

TEIXEIRA, M. O. A Escala multidimensional de auto-eficácia percebida: um estudo exploratório numa amostra de estudantes do ensino superior. Revista Iberoamericana de Diagnóstico y Evaluación Psicológica, v. 25, n. 1, p. 141-158, 2008.

TINTO, V. Dropout from higher education: a theoretical synthesis of recent research. Review of Educational Research, New York, n. 45, p. 89-125, 1975.

WARNER, J. Historical perspectives on the shifting boundaries around youth and alcohol: the example of pre-industrial England, 1350-1750. Addiction, v. 93, n. 5, p. 641-657, 1998.

ZIMMERMAN, B. J. Self-efficacy: an essential motive to learn. Contemporary Educational Psychology, v. 25, n. 1, p. 82-91, 2000. 